\title{
PENINGKATAN PELAKSANAAN KESELAMATAN PASIEN OLEH MAHASISWA MELALUI PERAN PEMBIMBING KLINIK
}

\author{
Lilis Suryani ${ }^{1}$, Hanny Handiyani² ${ }^{2}$ Sutanto Priyo Hastono ${ }^{3}$ \\ 1. Program Studi Magister Fakultas Ilmu Keperawatan, Universitas Indonesia, Depok 16424, Indonesia \\ 2. Fakultas Ilmu Keperawatan Universitas Indonesia, Depok 16424, Indonesia \\ 3. Fakultas Kesehatan Masyarakat Universitas Indonesia, Depok 16424, Indonesia \\ *E-mail: lilis_suryani73@yahoo.co.id
}

\begin{abstract}
Abstrak
Pembimbing klinik sangat berperan dalam proses pembelajaran mahasiswa yang melaksanakan tindakan langsung kepada pasien di rumah sakit, namun peran pembimbing masih belum optimal dalam memberikan pembimbingan yang menjamin keselamatan pasien. Penelitian ini bertujuan untuk mengidentifikasi hubungan peran pembimbing klinik dengan pelaksanaan keselamatan pasien oleh mahasiswa di rumah sakit. Responden penelitian sebanyak 196 mahasiswa tingkat akhir Sekolah Tinggi Keperawatan yang terdiri dari program Ners, D3 Keperawatan, dan D3 Kebidanan. Desain penelitian menggunakan pendekatan potong lintang. Analisis regresi logistik menyampaikan ada hubungan bermakna antara peran pembimbing klinik dengan pelaksanaan keselamatan pasien yang dilaksanakan oleh mahasiswa setelah dikontrol dengan jenis pendidikan $(\mathrm{p}=0,02 ; \mathrm{CI}=1,19-3,71)$. Rekomendasi antara lain peran pembimbing klinik perlu ditingkatkan dalam pelaksanaan keselamatan pasien oleh mahasiswa.
\end{abstract}

Kata kunci: keselamatan pasien, mahasiswa, peran pembimbing klinik

\begin{abstract}
The Improvement of Student's Behavior in Patient Safety towards Clinical Instructor's Role. Clinical instructor has an important role in student's learning process in implementing direct intervention toward patient within the hospital. The purpose of this study is to determine thecorrelation between the role of clinical instructor and patient safety implementation by the student in hospital. This is descriptive correlational method which is recruited 196 students in their final year in Stikes as respondents. These respondents were studying in bachelor nursing, diploma nursing and diploma in midwifery program. The study used cross sectional design. The result by regression logistic shows significant correlation between the role of clinical instructor and patient safety implementation by the student where education as a confounding factor were controlled $(p=0,02 ; C I=1,19-3,71)$. It is recommended that increase for clinical instructor in patient safety and implementation of patient safety by students.
\end{abstract}

Keywords: clinical instructor role, patient safety, student

\section{Pendahuluan}

Kelalaian individu merupakan ancaman terjadinya kejadian yang tidak diharapkan pada pasien. Institute Medicine of America melaporkan 100.000 orang meninggal setiap tahun sebagai akibat dari kesalahan medis, kesalahan berasal berasal dari efek samping obat, komplikasi bedah, kesalahan sistem, dan kesalahan pengobatan. Studi di Kanada didapatkan 7-12\% pasien di rumah sakit mengalami efek samping obat dan 30-40\% dari peristiwa itu dapat dicegah. Berdasarkan laporan tersebut maka penting untuk meningkatkan program keselamatan pasien (Forster, Dervin, Martin Jr., Papp, 2012; Montoya \& Kimbal, 2013). Sasaran program keselamatan pasien meliputi: ketepatan identifikasi pasien, komunikasi efektif, keamanan obat, kepastian tepat lokasi, tepat prosedur, tepat pasien, pengurangan risiko infeksi, dan pengurangan risiko pasien jatuh (Depkes RI, 2008; Permenkes, 2011).

Mahasiswa keperawatan yang sedang melaksanakan praktik di rumah sakit dapat juga 
melakukan suatu kesalahan. Mahasiswa sebagai faktor individu berpengaruh terhadap kualitas perawatan dan keselamatan pasien (Mwachofi, Walston, \& Al-Omar, 2011). Mahasiswa perlu melaksanakan dan menerapkan program keselamatan pasien sehingga dapat mencegah adanya cedera pada pasien. Implementasi sistem keselamatan pasien yang baik oleh mahasiswa dapat menghindari suatu kesalahan. Data pelaksanaan keselamatan pasien oleh mahasiswa STIKes X di RSUD Y masih terjadi suatu kesalahan antara lain kesalahan rute pemberian salah satu obat injeksi. Kesalahan yang dilakukan mahasiswa dimungkinkan karena tidak didampingi oleh pembimbing klinik. Pembimbing klinik banyak yang mempunyai kesibukan rangkap seperti kegiatan manajerial maupun tugas memberikan asuhan keperawatan. Kondisi ini menyebabkan bimbingan kepada mahasiswa menjadi kurang optimal. Proses pembelajaran selama mahasiswa praktik tentunya tidak lepas dari peran pembimbing klinik. Mahasiswa perlu mengintegrasikan keselamatan pasien dalam proses pembelajaran yang dilakukan kepada pasien dengan bimbingan dari para pembimbing klinik (Johnson, 2011; Gantt \& Corbett, 2010).

Pembimbing klinik sangat berperan dalam proses pembelajaran klinik dan pencapaian kompetensi (Johnson, 2011; Jecklin, 2009). Pembimbing klinik perlu memiliki keahlian klinis dan pengajaran sehingga dapat memberikan bimbingan yang berkualitas dan pencapaian kompetensi yang optimal (Dahlke, Baumbusch, Affleck, \& Kwon, 2012). Peran pembimbing klinik yang diperlukan antara lain sebagai pendidik, sebagai perawat profesional dan sebagai role model (Johnson 2011; Lewallen \& DeBrew, 2012; Tang, Chou, \& Chiang, 2005). Peran sebagai pendidik akan mengelola pembelajaran terkait keselamatan pasien, peran sebagai pemberi perawatan profesional akan memberikan pelayanan atau perawatan kepada pasien sebagai bagian dari proses pembelajaran dan peran memberi contoh kepada mahasiswa terkait pelaksanaan keselamatan pasien. Peran pembimbing yang baik dapat meningkatkan pencapaian kompetensi dan tujuan pembelajaran. Pembimbing klinik juga sangat berperan dalam proses pembelajaran klinik dan pencapaian kompetensi (Johnson, 2011; Jecklin, 2009), dan sangat penting perannya dalam menghasilkan lulusan yang profesional (Nurachmah, 2005). Peran pembimbing klinik dapat menentukan kualitas lulusan di masa mendatang. Pembimbing klinik diharapkan memiliki keahlian klinis dan pengajaran sehingga dapat memberikan bimbingan yang berkualitas dan pencapaian kompetensi yang optimal (Dahlke, et al., 2012).

Keselamatan pasien merupakan hak bagi setiap pasien, oleh karena itu keselamatan pasien harus mendapatkan prioritas untuk diperhatikan dan dilaksanakan. Terkait keberadaan mahasiswa yang sedang melaksanakan praktik di RS dan kaitannya dengan keamanan dan keselamatan pasien, maka sangat diperlukan peran pembimbing klinik dalam rangka menjaga keamanan dan keselamatan pasien serta pencapaian kompetensi pembelajaran, sehingga pada penelitian ini dianalisis hubungan peran pembimbing klinik dengan pelaksanaan keselamatan pasien yang dilakukan oleh mahasiswa.

\section{Metode}

Desain yang digunakan pada penelitian adalah korelasi dengan pendekatan potong lintang. Sampel berjumlah 196 mahasiswa STIKes tingkat akhir, yang terdiri terdiri dari 38 Prodi Ners, 56 D3 Keperawatan, dan 102 D3 Kebidanan. Instrumen yang digunakan terdiri dari tiga jenis yaitu kuesioner A tentang data demografi yang terdiri dari usia, jenis kelamin, tingkat pendidikan, pelatihan keselamatan pasien yang diikuti, sedangkan instrumen kedua yaitu kuesioner B tentang pelaksanaan keselamatan pasien oleh mahasiswa yang terdiri dari 33 item, meliputi aspek ketepatan identifikasi pasien, komunikasi efektif, pencegahan infeksi, dan pencegahan risiko pasien jatuh. Sedangkan instrumen ketiga yaitu kuesioner $\mathrm{C}$ tentang peran pembimbing. Item meliputi peran sebagai pendidik, peran sebagai pemberi perawatan profesional, dan peran sebagai role model. Hasil Uji coba instrumen pada kuesioner B dengan Alpa Cronbach 0,784, sedangkan pada kuesioner C dengan Alpha Cronbach 0,873. Analisis data dilakukan dengan menggunakan uji statistik Chi-Square. Penelitian 
ini telah lolos uji etik dari komite etik Fakultas Ilmu Keperawatan Indonesia.

\section{Hasil Penelitian}

Karakteristik Responden (Mahasiswa). Berdasarkan hasil penelitian yaitu mayoritas mahasiswa berusia dewasa muda, mayoritas perempuan, berpendidikan D3 Kebidanan dan sebagian besar pernah mendapatkan materi tentang keselamatan pasien.
Gambaran pelaksanaan keselamatan pasien oleh mahasiswa STIKes X yang melaksanakan praktik di RSUD Y secara umum menunjukkan 52\% masih kurang. Pelaksanaan keselamatan pasien yang sudah menunjukkan baik lebih dari $80 \%$ yaitu Prodi Ners. Gambaran peran pembimbing klinik RSUD Y pada mahasiswa STIKes X untuk setiap program studi rerata masih kurang.

Tabel 1. Karakteristik Mahasiswa Tingkat Akhir STIKes X Berdasarkan Usia, Jenis Kelamin, Tingkat Pendidikan, dan Pelatihan

\begin{tabular}{lcc}
\hline \multicolumn{1}{c}{ Varibel } & Frekuensi & Persen (\%) \\
\hline Usia & 176 & \\
$\leq 25$ tahun & 20 & 89,8 \\
>25tahun & & 10,2 \\
Jenis Pendidikan & 102 & \\
D3 Kebidanan & 56 & 52 \\
D3 Keperawatan & 38 & 28,6 \\
Ners & & 19,4 \\
Jenis Kelamin & 70 & \\
Laki-laki & 126 & 35,7 \\
Perempuan & & 64,3 \\
Pelatihan keselamatan pasien & 8 & 4,1 \\
Tidak pernah & 188 & 95,9 \\
Pernah & & \\
\hline
\end{tabular}

Tabel 2. Pelaksanaan Keselamatan Pasien oleh Mahasiswa STIKes X

\begin{tabular}{|c|c|c|c|c|c|c|}
\hline \multirow{3}{*}{ Jenis Pendidikan } & \multicolumn{4}{|c|}{ Pelaksanaan Keselamatan } & \multirow{2}{*}{\multicolumn{2}{|c|}{ Total }} \\
\hline & \multicolumn{2}{|c|}{ Kurang } & \multicolumn{2}{|c|}{ Baik } & & \\
\hline & $\mathbf{n}$ & $\%$ & $\mathbf{n}$ & $\%$ & $\mathbf{N}$ & $\%$ \\
\hline D3 Kebidanan & 65 & 63,7 & 37 & 36,3 & 102 & 100 \\
\hline D3 Keperawatan & 30 & 53,6 & 26 & 46,4 & 56 & 100 \\
\hline Ners & 7 & 18,4 & 31 & 81,6 & 38 & 100 \\
\hline Total & 102 & 52 & 94 & 48 & 196 & 100 \\
\hline
\end{tabular}

Tabel 3. Peran Pembimbing Klinik RSUD Y pada Mahasiswa STIKes X

\begin{tabular}{|c|c|c|c|c|c|c|}
\hline \multirow{3}{*}{ Jenis Pendidikan } & \multicolumn{4}{|c|}{ Peran Pembimbing Klinik } & \multirow{2}{*}{\multicolumn{2}{|c|}{ Total }} \\
\hline & & & & & & \\
\hline & $\mathbf{n}$ & $\%$ & $\mathbf{n}$ & $\%$ & $\mathbf{n}$ & $\%$ \\
\hline D3 Kebidanan & 42 & 41.2 & 60 & 58.8 & 102 & 100 \\
\hline D3 Keperawatan & 39 & 69.6 & 17 & 30.4 & 56 & 100 \\
\hline Ners & 19 & 50 & 19 & 50 & 38 & 100 \\
\hline Total & 100 & 51 & 96 & 49 & 196 & 100 \\
\hline
\end{tabular}


Tabel 4. Hubungan Peran Pembimbing Klinik dengan Pelaksanaan Keselamatan Pasien oleh Mahasiswa STIKes X

\begin{tabular}{|c|c|c|c|c|c|c|c|c|}
\hline \multirow{3}{*}{ Peran } & \multicolumn{4}{|c|}{$\begin{array}{c}\text { Pelaksanaan Keselamatan Pasien Oleh } \\
\text { Mahasiswa }\end{array}$} & \multirow{2}{*}{\multicolumn{2}{|c|}{ Total }} & \multirow{3}{*}{$\begin{array}{l}\text { OR } \\
(\mathbf{9 5 \%})\end{array}$} & \multirow{3}{*}{$\mathbf{p}$} \\
\hline & \multicolumn{2}{|c|}{ Kurang } & \multicolumn{2}{|c|}{ Baik } & & & & \\
\hline & $\mathrm{n}$ & $\%$ & $\mathrm{n}$ & $\%$ & $\mathbf{n}$ & $\%$ & & \\
\hline Kurang & 61 & 61,0 & 39 & 39,0 & 100 & 100 & 20 & \\
\hline Baik & 41 & 42,7 & 55 & 57,3 & 96 & 100 & $(1,19-3,71)$ & $0,016^{*}$ \\
\hline Total & 102 & 52 & 94 & 48 & 196 & 100 & & \\
\hline
\end{tabular}

Tabel 5. Hubungan Karakteristik dengan Pelaksanaan Keselamatan Pasien oleh Mahasiswa STIKes X

\begin{tabular}{|c|c|c|c|c|c|c|c|c|}
\hline \multirow{3}{*}{ Kategori } & \multicolumn{4}{|c|}{$\begin{array}{c}\text { Pelaksanaan Keselamatan Pasien } \\
\text { oleh Mahasiswa }\end{array}$} & \multirow{2}{*}{\multicolumn{2}{|c|}{ Total }} & \multirow[t]{3}{*}{$\begin{array}{c}\text { OR } \\
(95 \% \mathrm{CI})\end{array}$} & \multirow[t]{3}{*}{$\mathbf{p}$} \\
\hline & \multicolumn{2}{|c|}{ Kurang } & \multicolumn{2}{|c|}{ Baik } & & & & \\
\hline & $\mathbf{N}$ & $\%$ & $\mathbf{n}$ & $\%$ & $\mathbf{n}$ & $\%$ & & \\
\hline \multicolumn{9}{|l|}{ Usia } \\
\hline$\leq 25$ tahun & 101 & 57,4 & 75 & 42,6 & 176 & 100 & \multirow{3}{*}{$\begin{array}{c}2,559 \\
(3,35-19,54)\end{array}$} & \multirow{3}{*}{$0,0001 *$} \\
\hline$>25$ tahun & 1 & 5 & 19 & 95 & 20 & 100 & & \\
\hline Total & 102 & 52 & 94 & 48 & 196 & 100 & & \\
\hline \multicolumn{9}{|l|}{ Jenis Pendidikan } \\
\hline D3 Kebidanan & 65 & 63,7 & 37 & 36,3 & 102 & 100 & \multirow{2}{*}{$\begin{array}{c}1,52 \\
(-0,24-1,08)\end{array}$} & \multirow[t]{3}{*}{$0,006^{*}$} \\
\hline D3 Keperawatan & 30 & 53,6 & 26 & 46,4 & 56 & 100 & & \\
\hline Ners & 7 & 18,4 & 31 & 81,6 & 38 & 100 & \multirow[t]{2}{*}{$\begin{array}{c}7,78 \\
(1,14-2,96)\end{array}$} & \\
\hline Total & 102 & 52 & 94 & 48 & 196 & 100 & & \\
\hline \multicolumn{9}{|l|}{ Jenis Kelamin } \\
\hline Laki-laki & 31 & 44,3 & 39 & 55,7 & 70 & 100 & \multirow{3}{*}{$\begin{array}{c}0,616 \\
(0,34-1,11)\end{array}$} & \multirow[t]{3}{*}{0,141} \\
\hline Perempuan & 71 & 56,3 & 55 & 43,7 & 126 & 100 & & \\
\hline Total & 102 & 52,0 & 94 & 48,0 & 196 & 100 & & \\
\hline \multicolumn{9}{|l|}{ Pelatihan } \\
\hline Tidak Pernah & 6 & 75 & 2 & 25 & 8 & 100 & \multirow{3}{*}{$\begin{array}{c}2,875 \\
(0,57-14,6)\end{array}$} & \multirow[t]{3}{*}{0,334} \\
\hline Pernah & 96 & 51,1 & 92 & 48,9 & 188 & 100 & & \\
\hline Total & 102 & 52 & 94 & 48 & 196 & 100 & & \\
\hline
\end{tabular}

*Bermakna pada $\alpha 0,05$

Hubungan Peran Pembimbing Klinik dengan Pelaksanaan Keselamatan Pasien oleh Mahasiswa. Hasil uji statistik didapatkan bahwa ada hubungan yang bermakna antara peran pembimbing klinik dengan pelaksanaan keselamatan pasien oleh mahasiswa di RSUD Y, dibuktikan dengan p yang bermakna yaitu 0,016 . Dari hasil analisis diperoleh pula nilai $\mathrm{OR}=2,098$, artinya dengan peran pembimbing yang kurang, maka mahasiswa berisiko 2,098 kali lebih besar untuk melaksanakan keselamatan pasien dengan kurang dibandingkan pada peran pembimbing yang baik.

Hubungan Karakteristik Mahasiswa dengan Pelaksanaan Keselamatan Pasien oleh Mahasiswa. Pada Tabel 5 menunjukkan 2 (dua) variabel yang berhubungan dengan pelaksanaan keselamatan pasien yang dipersepsikan oleh mahasiswa yaitu variabel usia $(\mathrm{p}=0,0001)$ dan jenis pendidikan $(p=0,006)$. Pada Tabel 6 memperlihatkan hasil 
Tabel 6. Pemodelan Akhir Regresi Logistik Peran Pembimbing Klinik dengan Pelaksanaan Keselamatan Pasien oleh Mahasiswa

\begin{tabular}{lccc}
\hline \multicolumn{1}{c}{ Variabel } & B & p & OR \\
\hline Peran Pembimbing(1) & 1,017 & 0,002 & 2,766 \\
Jenis Pendidikan & & 0,000 & \\
pendidikan(1) & 0,747 & 0,043 & 2,111 \\
pendidikan(2) & 2,260 & 0,000 & 9,586 \\
Constant & $-1,200$ & 0,000 & 0,301 \\
\hline
\end{tabular}

analisis multivariat yaitu menunjukkan bahwa peran pembimbing klinik berhubungan dengan pelaksanaan keselamatan pasien oleh mahasiswa setelah dikontrol dengan jenis pendidikan. Hasil analisis didapatkan peran pembimbing yang kurang berisiko 2,76 kali lebih besar untuk melaksanakan keselamatan pasien yang kurang oleh mahasiswa dibandingkan dengan mahasiswa yang mendapatkan peran pembimbing yang baik.

\section{Pembahasan}

\section{Peran Pembimbing Klinik dengan Pelaksanaan} Keselamatan Pasien oleh Mahasiswa. Hasil penelitian menunjukkan bahwa peran pembimbing klinik masih kurang. Hal yang menyebabkan peran pembimbing klinik masih kurang di RSUD $\mathrm{Y}$ adalah pembimbing klinik sebagian besar masih merangkap jabatan sebagai kepala ruangan dan belum mendapatkan pelatihan tentang keselamatan pasien, sehingga bimbingan yang dilakukan kepada mahasiswa menjadi kurang optimal. Pembimbingan yang kurang dapat mengakibatkan pelaksanaan keselamatan pasien yang dilakukan oleh mahasiswa pun menjadi kurang. Mahasiswa yang selama praktik di rumah sakit dapat melaksanakan asuhan atau tindakan secara langsung kepada pasien (Lewallen \& DeBrew, 2012; Tang, et al., 2005). Peran pembimbing klinik akan menentukan dalam pencapaian kompetensi pembelajaran khususnya kompetensi terkait keselamatan pasien. Hal ini sejalan dengan yang disampaikan oleh Parsh (2010), bahwa pembimbing klinik yang memiliki pengetahuan dan keterampilan yang baik, maka akan dapat membantu mahasiswa untuk memperoleh penge- tahuan dan keterampilan. Pembimbing klinik sangat berperan dalam proses pembelajaran klinik bagi mahasiswa untuk mencapai tujuan pembelajaran (Johnson, 2011; Jecklin, 2009).

Pembimbing klinik perlu memiliki keahlian klinis dan pengajaran sehingga dapat memberikan bimbingan yang berkualitas (Dahlke, et al., 2012). Peran pembimbing klinik yang kurang dalam penelitian ini meliputi peran sebagai pendidik, pemberi pelayanan keperawatan profesional kepada pasien dan sebagai role model terkait keselamatan pasien. Peran sebagai pendidik meliputi peran dalam mempersiapkan mahasiswa terutama dalam mengelola pembelajaran, melaksanakan pembelajaran, dan mengevaluasi pembelajaran (Tang, et al., 2005). Peran sebagai pendidik dapat mencapai tujuan pembelajaran dan meningkatkan percaya diri serta kepuasan mahasiswa (Parsh, 2010). Peran sebagai pemberi perawatan profesional kepada pasien, pembimbing dapat melakukan pelayanan kepada pasien sebagai bagian dari proses pembelajaran kepada mahasiswa.

Pembimbing klinik dapat melibatkan pasien dalam proses pembelajaran kepada mahasiswa tetapi dengan tetap menjaga dan melindungi pasien (Dahlke, et al., 2012). Hal ini juga sejalan dengan yang disampaikan oleh Johnson (2011) dan Kim, Park, dan Kang (2013), bahwa peran sebagai perawat profesional yaitu peran sebagai pemberi asuhan keperawatan kepada pasien, mulai dari kemampuan melakukan pengkajian sampai dengan melakukan evaluasi kepada pasien serta kemampuan memberikan umpan balik. Peran pembimbing klinik sebagai role model 
merupakan peran yang dapat memberikan contoh bagi mahasiswa untuk menjelaskan dan mendemonstrasikan teknik-teknik terkait pelaksanaan keselamatan pasien dan diharapkan memberikan contoh yang meliputi perilaku dan sikap positif (Beth, 2009; Kim, et al., 2013). Jika peran pembimbing klinik kurang maka proses bimbingan dan pencapaian tujuan akan menjadi kurang optimal terkait pelaksanaan keselamatan pasien yang meliputi penerapan sasaran keselamatan pasien terdiri dari ketepatan identifikasi pasien, peningkatan komunikasi yang efektif, peningkatan keamanan obat yang perlu diwaspadai, pengurangan risiko infeksi, dan pengurangan risiko pasien jatuh (Depkes, 2008).

Keberadaan mahasiswa di rumah sakit walaupun sedang belajar tetap perlu menjaga keselamatan pasien. Keselamatan pasien rumah sakit merupakan suatu sistem yang ada di rumah sakit yang membuat asuhan pasien lebih aman dan bebas dari cedera yang tidak disengaja (Montoya \& Kimbal, 2013; Permenkes, 2011). Mahasiswa perlu mengintegrasikan keselamatan pasien dalam proses pembelajaran yang dilakukan kepada pasien (Johnson, 2011; Gantt \& Corbett, 2010). Peran pembimbing klinik sangat penting dalam membantu memfasilitasi proses pembelajaran dan peran pembimbing berhubungan dengan pelaksanaan keselamatan pasien oleh mahasiswa.

\section{Hubungan Karakteristik Mahasiswa dengan Pelaksanaan Keselamatan Pasien oleh Mahasis-} wa. Hasil analisis menunjukkan ada hubungan antara usia dengan pelaksanaan keselamatan pasien oleh mahasiswa. Hasil analisis menunjukkan semakin muda usia mahasiswa sama atau kurang dari 25 tahun, semakin risiko kurang baik dalam pelaksanaan keselamatan pasien. Sedangkan usia lebih dari 25 tahun semakin baik dalam pelaksanaan keselamatan pasien oleh mahasiswa. Hal ini sejalan dengan yang dikemukakan oleh Robbin (2003) bahwa pertambahan usia berhubungan erat dengan kemampuan analisis terhadap permasalahan yang dihadapi, komitmen untuk ke arah lebih baik, dan dapat mengendalikan emosi lebih baik. Hasil analisis menunjukkan jenis pendidikan berhubungan dengan pelaksanaan keselamatan pasien. Jenis pendidikan pada penelitian ini yaitu Prodi Ners, D3 Keperawatan, dan D3 Kebidanan. Jika dilihat dari proporsi pelaksanaan keselamatan pasien yang lebih baik adalah Prodi Ners dibandingkan D3 Keperawatan maupun D3 Kebidanan. Semakin tinggi pendidikan kemungkinan semakin tinggi pula kemampuan dan daya nalar mahasiswa, sehingga mahasiswa dapat dengan mudah untuk menyelesaikan masalah yang dihadapi. Hal ini sejalan dengan penelitian Anugrahini, Sahar, dan Mustikasari (2010) yang menerangkan bahwa tingkat pendidikan S1 dan D3 Keperawatan lebih patuh dari perawat berpendidikan SPK.

Hasil analisis menunjukkan tidak ada hubungan antara jenis kelamin dengan pelaksanaan keselamatan pasien oleh mahasiswa. Hal ini sejalan dengan pendapat Robbin (2003) yang menyatakan bahwa tidak terdapat perbedaan pada pria dan wanita dalam hal kemampuan memecahkan masalah, keterampilan analisis, persaingan, motivasi, maupun kemampuan belajarnya.

Peneliti menganalisis tidak adanya hubungan antara jenis kelamin dengan pelaksanaan keselamatan pasien disebabkan karena mayoritas pada penelitian ini adalah perempuan, bahkan untuk prodi D3 Kebidanan 100\% perempuan. Hal ini menjadi pertimbangan bahwa pada dasarnya terdapat kesamaan dalam pelaksanaan keselamatan pasien oleh mahasiswa. Perbedaan jenis kelamin tidak menjadi masalah bagi mahasiswa dalam melaksanakan keselamatan pasien.

\section{Hubungan Pelatihan dengan Pelaksanaan} Keselamatan pasien. Hasil analisis menunjukkan tidak ada hubungan antara pelatihan dengan pelaksanaan keselamatan pasien oleh mahasiswa. Hal ini tidak sejalan dengan Gregory, et al., (2007), pelatihan sangat diperlukan bagi mahasiswa untuk meningkatkan kemampuan mahasiswa terkait keselamatan pasien. Yulia, Hamid, dan Mustikasari (2012) menerangkan bahwa pelatihan berpengaruh terhadap pemahaman perawat pelaksana dalam penerapan keselamatan pasien. Peneliti menganalisis tidak adanya hubungan antara pelatihan dengan pelaksanaan keselamatan pasien oleh mahasiswa STIKes X yaitu pelatihan tentang keselamatan pasien merupakan bagian akhir 
dari mata kuliah yang perlu diikuti oleh seluruh mahasiswa di akhir perkuliahan, sehingga sebagian besar mahasiswa telah mengikuti pelatihan ini yaitu lebih dari $95 \%$.

\section{Kesimpulan}

Kesimpulan hasil penelitian adalah terdapat hubungan signifikan antara peran pembimbing klinik dengan pelaksanaan keselamatan pasien oleh mahasiswa. Setelah dikontrol oleh pendidikan, peran pembimbing yang kurang akan memberikan risiko 2,766 kali lebih besar untuk mahasiswa melaksanakan kese-lamatan pasien yang kurang jika dibandingkan dengan kelompok mahasiswa yang peran pembimbingnya baik.

Hasil penelitian ini dapat membantu pembimbing klinik untuk lebih meningkatkan perannya yang meliputi peran sebagai pendidik, sebagai pemberi pelayanan keperawatan kepada pasien, dan peran sebagai role model terkait pelaksanaan keselamatan pasien. Peningkatan peran pembimbing klinik antara lain dengan meningkatkan pengetahuan melalui pelatihan terkait program keselamatan pasien sehingga perannya akan lebih baik. Mahasiswa dapat meningkatkan pengetahuan terkait program keselamatan pasien. Berdasarkan penelitian ini, dapat dilakukan penelitian selanjutnya dengan metode penelitian observasi langsung dari pelaksanaan bimbingan klinik oleh pembimbing dan observasi langsung pelaksanaan keselamatan pasien oleh mahasiswa (RR, INR, AR).

\section{Referensi}

Anugrahini, C., Sahar, J., \& Mustikasari. (2010). Kepatuhan perawat menerapkan pedoman patient safety berdasarkan faktor individu dan organisasi. Jurnal Keperawatan Indonesia, 13(3), 139-144.

Beth, P. (2009). Role modeling excellence in clinical nursing practice. Nurse Education in Practice, 9(1), 36-44. Doi: http://dx.doi.org/ 10.1016/j.nepr.2008.05.001.
Dahlke, S., Baumbusch, J., Affleck, F., \& Kwon, J. (2012). The clinical instructor role in nursing education: A structured literature review. Journal of Nursing Education, 51(12), 692696. Doi: http://dx.doi.org/10.3928/0148483420121022-01.

Depkes RI. (2008). Panduan nasional keselamatan pasien rumah sakit (patient safety) (Edisi ke-2). Jakarta: Depkes.

Forster, A.J., Dervin, G., Martin Jr., C., Papp, S. (2012). Improving patient safety through the systematic evaluation of patient outcomes. Canadian Journal of Surgery, 55(6), 418425. Diperoleh dari http://search.proquest. com/docview/1282102486?accountid=17242.

Frush, K.S., Alton, M., \& Frush, D. (2006). Development and implementation of hospitalbased patient safety program. Pediatr Radiol, 36, 241-298. Doi 10.1007/s 00247-006-01207.

Gantt, L.T., \& Corbett, W.R. (2010). Using simulation to teach patient safety behaviors in undergraduate nursing education. Journal of Nursing Education, 49(1), 48-51. Diperoleh dari http://search.proquest.com/docview/203 965336? accountid=17242.

Johnson, S. (2011). Preceptor-guided clinical practicum orientation manual. School of Nursing Virginia Commonwealth University. Diperoleh dari Johnson, S. (2011). http://www.nursing.vcu.edu/media/schoolofnursing/docs/resources/PreceptorGuidedClin icalPracticum_OrientationManual_rev2016. pdf

Jecklin, S.K. (2009). Assessing nursing student perceptions of the clinical learning environment: Refinement and testing of the SECEE inventory. Journal of Nursing Measurement, 17(3), 232-246. Diperoleh dari http://search. proquest.com/docview/206332547?accounti $\mathrm{d}=17242$.

Kim, C., Park, J., \& Kang, S. (2013). Effects of a collaborative clinical practicum on clinical practice ability and teaching effectiveness among nursing students. Journal of Nursing Education and Practice, 3(12), 143. 
Diperoleh dari http://search.proquest.com/ docview/1431143158?accountid=17242.

Lewallen, L.P., \& DeBrew, J.K. (2012). Successful and unsuccessful clinical nursing students. Journal of Nursing Education, 51(7), 389395. Doi: http://dx.doi.org/10.3928/01484 834-20120427-01.

Mwachofi, A., Walston, S.L., \& Al-Omar, B. (2011). Factors affecting nurses' perceptions of patient safety. International Journal of Health Care Quality Assurance, 24(4), 274283. Doi: http://dx.doi.org/10.1108/0952686 1111125589 .

Montoya, I.D., Kimbal, O.M. (2013). Gauging patient safety program. Journal of allied health, 42(3).

Nurachmah, E. (2005). Metode pengajaran klinik keperawatan. Makalah pelatihan bimbingan klinik FIK UI. Tidak dipublikasikan.

Parsh, B. (2010). Characteristics of effective simulated clinical experience instructors: Interviews with undergraduate nursing students. Journal of Nursing Education, 49(10), 569-572. Doi: http://dx.doi.org/10. 3928/01484834-20100730-04

Menteri Kesehatan RI. (2011). Peraturan Menteri kesehatan Nomor 1691/MENKES/PER/VIII/ 2011 tentang keselamatan pasien rumah sakit. Jakarta: Kemenkes RI.

Robbin, S.P. (2003). Perilaku organisasi. (Edisi ke-10). Jakarta: PT. Indeks Gramedia.

Tang, Chou, S., \& Chiang, H. (2005). Students' perceptions of effective and ineffective clinical instructors. Journal of Nursing Education, 44(4), 187-192. Diperoleh dari http://search.proquest.com/docview/203931 594? accountid=17242.

Yulia, S., Hamid, A.Y., \& Mustikasari. (2012). Peningkatan Pemahaman Perawat Pelaksana dalam Penerapan Keselamatan Pasien Melalui Pelatihan Keselamatan Pasien. Jurnal Keperawatan Indonesia, 15(3), 185-192. 